\title{
Genetic diversity in commercial varieties of chilli as revealed by RAPD method H. K. Makari ${ }^{1}$, H. S. Ravikumar Patil ${ }^{1}$, M. Abhilash ${ }^{2}$ and H. D. Mohan Kumar ${ }^{3}$ ${ }^{1}$ Dept. of Biotech., G.M. Instt. of Technol., Davangere, ,'The Oxford College of Engg., Bangalore, Karnataka, India ${ }^{3}$ Dept. of Plant Breeding \& Genetics, Agri. Res. Station, Univ. Agri. Sci., Devihosur, Haveri, Karnataka, India mac.gmit@gmail.com
}

Abstract: The study aimed at investigating the genetic diversity of ten different commercial varieties of chilli using random amplified polymorphic DNA (RAPD) analysis. The DNA extracted by CTAB method from the leaf sample was amplified by successive PCR cycles. Using 12 different primers, the amplified DNA solution was subjected to agarose gel electrophoresis. Around 500 different bands were observed under UV light. Seven were polymorphic for a specific primer and can be used as differential markers. This effort can serve determining genetic diversity among ten commercial varieties of chilli in India.

Keywords: Chilli, RAPD, molecular markers, RFLP Introduction

Capsicum is one of the most popular and widely grown vegetable in India. The fruit of Capsicum plants have a variety of names with reference to place and type. They are commonly known as chilli pepper, capsicum, red or green pepper, or sweet pepper in Britain, and typically just capsicum in Australia and India. Molecular markers are important tool for genotype identification and studying the organisation and evaluation of plant genome (Joseph,1993). With the advent of molecular biology technique, large number of highly useful DNA markers has been developed for the identification of genetic polymorphism. RAPD markers are amplification product of anonymous DNA sequence.

Capsicum contains approximately 20-27 species, five of which are domesticated: Capsicum annuum, $C$. baccatum, $C$. chinense, $C$. frutescens, and $C$. pubescens. The fruit of most species of Capsicum contains capsaicin (methyl vanillyl nonenamide), a lipophilic chemical that can produce a strong burning sensation in the mouth of the unaccustomed eater. The amount of capsaicin in Capsicum is highly variable and dependent on genetics, giving almost all types of Capsicum varied amounts of perceived heat. The only Capsicum without capsaicin is that cultivar of Capsicum annuum that is known as the bell pepper, which has a zero rating on the Scoville scale. Chilli peppers are of great importance in Native American medicine, and capsaicin is used in modern Western medicine - mainly in topical medications- as a circulatory stimulant and pain reliever. Jordi Ballester and Carmen de Vicente (1998) worked on Determination of F1 hybrid seed purity in pepper using PCR based marker. They used two PCR based markers i.e. RAPD (Random Amplified Polymorphic DNA) and SPARs (Single Primer Amplification Reaction).

Kevin D. Livingstone et al. (1999) carried out research work to create a genetic map of Capsicum (pepper) from an interspecific $F_{2}$ population consisting of 11 large and 2 small linkage groups. James R. Blauth et al. (1998) did study in the field of comparative plant genomics by two studies in the Solanaceae relating the genetic maps of tomato and potato (Bonierbale, 1988) and tomato and pepper (Tanksley et al., 1988), each of which was constructed using common restriction fragment length polymorphism (RFLP) probes.

Eyal Blum et al. (2003) carried out experiments on Molecular Mapping of Capsaicinoid Biosynthesis Genes and QTL (Quantitative Trait Loci) analysis for capsaicinoid content in Capsicum. Sun LingYun et al. (2005) carried out RAPD analysis of chilli (C. annum) germplasms. RAPD analysis was employed to analyse 34 chilli (pimiento) cultivars and its 22 primers amplified 119 bands of which 67 were polymorphic. Genetic fingerprinting, DNA testing, DNA typing, and DNA profiling are techniques used to distinguish between individuals of the same species using only samples of their DNA. With these backgrounds the objective of the study was set to find out genetic variation and diversity of commercial and cultivated varieties of chilli in local area of Karnataka State in India.

Materials and methods Plant material and DNA extraction

Ten different commercial verities of chilly were harvested from Chilli Research Centre Devihosur, Haveri District, Karnataka, India. Young leaves without necrotic lesions and older leaves which are not senescent were used for DNA extraction.

Extraction of DNA by mini preparation (rapid) method

Leaves were folded into $10-15 \mathrm{~cm}$ sections and were placed in aluminium foil along with the tag identifying the sample. It was then placed in container with ice to keep samples cool during the transit. The leaf samples were stored at $-80^{\circ} \mathrm{C}$ until they were ground (Angelo \& Peter, 2003).

\section{DNA Quantification}

UV Spectrophotometric method. Nucleic acids have an absorption maximum at $260 \mathrm{~nm}$. Most samples contain contaminates such as proteins and single stranded DNA/RNA that absorb maximally at $280 \mathrm{~nm}$. The equation for calculating DNA in the presence of contaminates is $A$ [260] /A [280] = pure dsDNA , The higher the ratio, the more pure the DNA sample. It is acceptable to have a ratio between 1.8 and 2.0.

Agarose gel electrophoresis method. 0.8\% agarose gel was prepared and DNA $(2 \mu \mathrm{l})$ was loaded with standard check $(\lambda$ DNA) and electrophoresed for $1-1 / 2$ hours. The intensity of bands was compared to assess relative concentration of DNA in each of the samples.

$R A P D$ analysis
Research article

CIndian Society for Education and Environment (iSee)
"Molecular marker for chilli" http://www.indjst.org
Makari et al. Indian J.Sci.Technol. 
Amplification of DNA using Polymerase Chain Reaction (PCR): Amplification of selected region from a complex

DNA mixture was carried out in vitro by the PCR method (Ratanacherdchai et al., 2007).

Diversity analysis of samples using agarose gel electrophoresis

DNA band scoring and interpretation: Electrophorased gel was subjected to DNA band scoring and interpretation for genotypic data. There are different types of interpretation and scoring data following the banding pattern for different types of PCR amplification.

Result and discussion

DNA quantification

$\begin{array}{ccccc}\begin{array}{c}\text { Sample } \\ \text { DNA } \\ (\mu \mathrm{l})\end{array} & \begin{array}{c}\text { 1X TAE } \\ \text { Buffer } \\ (\mu \mathrm{l})\end{array} & \begin{array}{c}\text { Absorbance } \\ @ 260 \mathrm{~nm}\end{array} & \begin{array}{c}\text { Absorbance } \\ @ ~ 280 \mathrm{~nm}\end{array} & \begin{array}{c}\text { Absorbance } \\ \text { Ratio } \\ 260: 280\end{array} \\ 10 & 990 & 0.214 & 0.118 & 1.81 \\ 10 & 990 & 0.198 & 0.109 & 1.81 \\ 10 & 990 & 0.212 & 0.122 & 1.73 \\ 10 & 990 & 0.167 & 0.102 & 1.63 \\ 10 & 990 & 0.051 & 0.029 & 1.75 \\ 10 & 990 & 0.113 & 0.059 & 1.91 \\ 10 & 990 & 0.108 & 0.059 & 1.83 \\ 10 & 990 & 0.175 & 0.096 & 1.82 \\ 10 & 990 & 0.109 & 0.062 & 1.75 \\ 10 & 990 & 0.154 & 0.080 & 1.92\end{array}$

The absorbance ratio for $260 \mathrm{~nm}: 280 \mathrm{~nm}$ was found to be in between 1.85-2.00 which means that the sample had pure DNA in good amount.

Diversity analysis of samples using agarose gel electrophoresis

With the primer OPA 02 (Fig. 1), amplification was observed in all the varieties except in the $9^{\text {th }}$ one that is P.S. varieties Dyavnoor1, 2, 3, 4, 5, PantC-1, \& P.Lal showed monomorphic band in the range of $2000 \mathrm{bp}$ to $1500 \mathrm{bp}$ with reference to DNA ladder. Another monomorphic band was observed in Dyavnoor2, 3 \& Dyavnoor4 in the range of $1500 \mathrm{bp} \& 1000 \mathrm{bp}$ with reference to DNA ladder. A polymorphic band observed in the chilli variety P.Lal. in the range of $1000 \mathrm{bp} \& 600 \mathrm{bp}$. Hence it can be used as differential marker.

With primer OPA 10 (Fig. 2) amplification was observed in all the chilli varieties except in last one that is F-112. Varying monomorphic band is seen in the range of $1000 \mathrm{bp}$ to $600 \mathrm{bp}$ in all variety except Dyavnoor 1 \& F112. Likewise varying monomorphic bands are seen in all the varieties in the range of $600 \mathrm{bp}$ to $300 \mathrm{bp}$.
Vol.2 No 4 (Apr. 2009) ISSN: 0974- 6846

With primer OPAB02 (Fig. 3) amplification was observed in all the varieties except Dyavnoor5, P.Lal \& F-112. Clear monomorphic band can be seen in the chilli varieties Dyavnoor1, 2, 3, 4, \& P.S in the range of $1500 \mathrm{bp}$ to $1000 \mathrm{bp}$. A polymorphic band was observed in variety LCA-235 in the range of $1000 \mathrm{bp}$ to $600 \mathrm{bp}$. Hence it can be used as differential marker.

With primer OPAB04 (Fig. 4) amplification was observed in Dyavnoor4, Dyavnoor5, LCA-235, P.S, F-112 with reference to DNA ladder. Between 500bp to 1000bp, Dyavnoor4,5,P.S,F-112 showed monomorphic band pattern in the same range where P.S \& F-112 showed two monomorphic band. In the same range Dyavnoor4,5,LCA-235,P.S,F-112 showed monomorphic band, Between 1500bp to 2000bp. Dyavnoor4 \& LCA-235 showed monomorphic band and can be used as differential marker.

With primer OPAB06 (Fig. 5) amplification was seen in all varieties except Dyavnoor2 \& Dyavnoor3. A monomorphic band was observed in the chilli varieties Dyavnoor1 \& Dyavnoor4 in the range 2000bp to $1500 \mathrm{bp}$ with reference to DNA ladder. A single polymorphic band was observed in Dyavnoor4 in the range of $1000 \mathrm{bp}$ to $600 \mathrm{bp}$ so it can be used as the marker for the Dyavnoor4 chilli variety.

With primer OPAB09 (Fig. 6) Amplification was observed in all the varieties of chilli and varies monomorphic band was observed in nearly all the varieties other than PantC- 1 chilli variety which was found to be less amplified. Amplification was not observed in any of the chilli varieties with the primer OPAB10 (Fig. 7). With primer OPAB14 (Fig. 8) amplification was observed in all the chilli variety, except in the Dyavnoor1, a monomorphic band can be seen in all amplified varieties in the range of $2000 \mathrm{bp}$ to $1500 \mathrm{bp}$ with reference to DNA ladder. In the same range, monomorphic band can be seen with Dyavnoor3, Dyavnoor4, Dyavnoor5, P.Lal, LCA-235, P.S \& F-112. Another monomorphic band can also be seen in the range of $100 \mathrm{bp}$ to $600 \mathrm{bp}$ in the chilli variety Dyavnoor3, Dyavnoor4, P.Lal \& P.S.

With the primer OPA18 (Fig. 9), amplification was observed in Dyavnoor3, Dyavnoor4, Dyavnoor5, PantC-1, P.Lal, LCA-235 \& P.S varieties of chilli. A monomorphic band can be observed between Dyavnoor3 \& LCA-235 in the range of $2000 \mathrm{bp}$ to $1500 \mathrm{bp}$ with reference to DNA ladder. In the range $1500 \mathrm{bp}$ to $100 \mathrm{bp}$ a polymorphic band was observed in variety LCA-235. In the same range a monomorphic band was seen in Dyavnoor3 \& LCA-235. Another polymorphic band was observed in the range $600 \mathrm{bp}$ to $300 \mathrm{bp}$ in the chilli variety Dyavnoor5. Hence
Research article

CIndian Society for Education and Environment (iSee)
"Molecular marker for chilli" http://www.indjst.org
Makari et al. Indian J.Sci.Technol. 
these polymorphic bands can be used as marker for respective varieties.

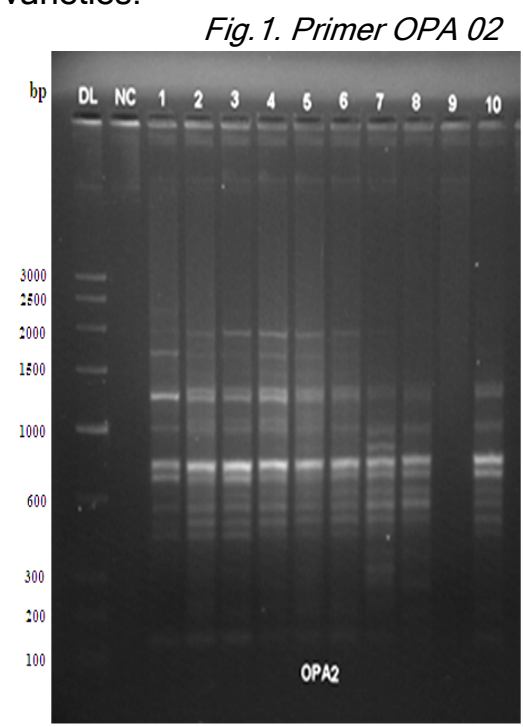

Fig.3. Primer OPAB 02

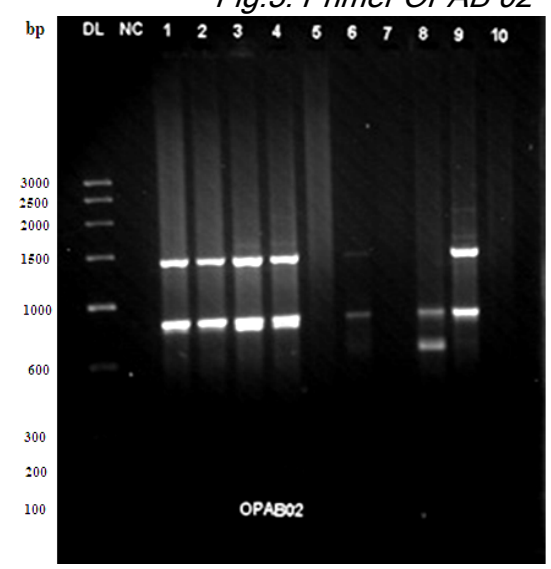

Fig.5. Primer OPAB 06

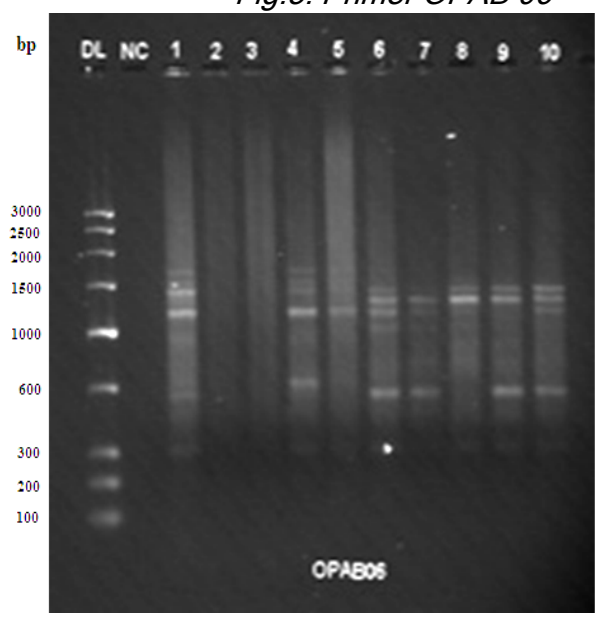

1. Dyavnoor 1

2. Dyarnoor 2

3. Dyavnoor 3

4. Dyarnoor 4

5. Dyavnoor 5

6. Pant C-1

7. P.Lal

8. LCA-235

9. P.S

10. F-112
1. Dyavnoor 1

2. Dyarnoor 2

3. Dyarnoor 3

4. Dyarnoor 4

5. Dyarnoor 5

6. Pant C-1

7. P.Lal

8. LCA-235

9. P.S

10. F-112

Amplification was not observed in any of the variety with primer OPAB20 (Fig. 10).

Fig.2. Primer OPA 10

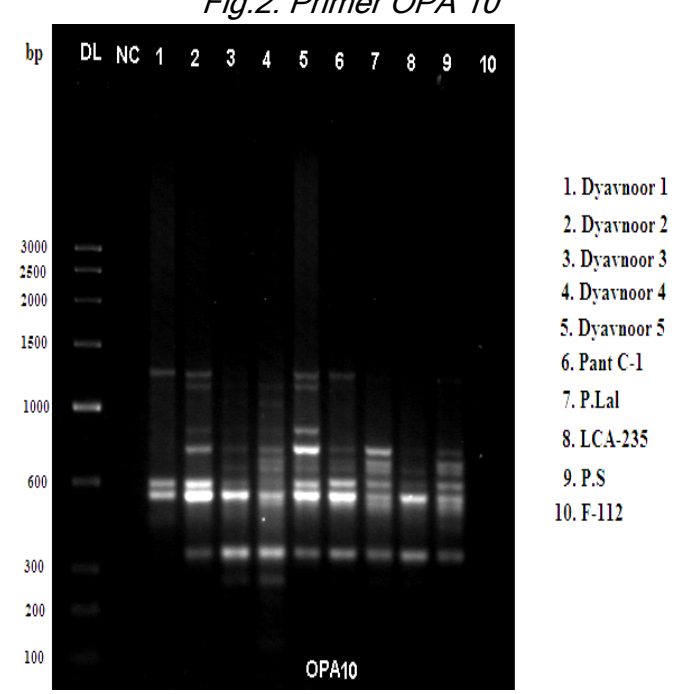

Fig.4. Primer OPAB 04

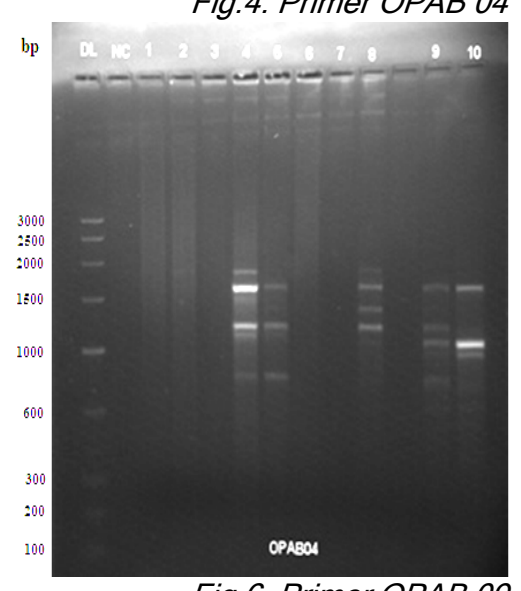

1. Dyarnoor 1

2. Dyarnoor 2

3. Dyarnoor 3

4. Dyarnoor 4

5. Dyarnoor 5

6. Pant C-1

7. P.Lal

8. LC. 235

9. P.S

10. F-112

With the primer OPP 13 (Fig. 11) amplification observed in the entire sample except sample in Dyavnoor5. With reference to DNA ladder between 1500bp to1000bp, Dyavnoor1, Dyavnoor2, Dyavnoor4 \& LCA-235 showed one monomorphic band whereas the same band was not observed in P.Lal, P.S \& F-112. A

Research article

CIndian Society for Education and Environment (iSee)
"Molecular marker for chilli" http://www.indjst.org

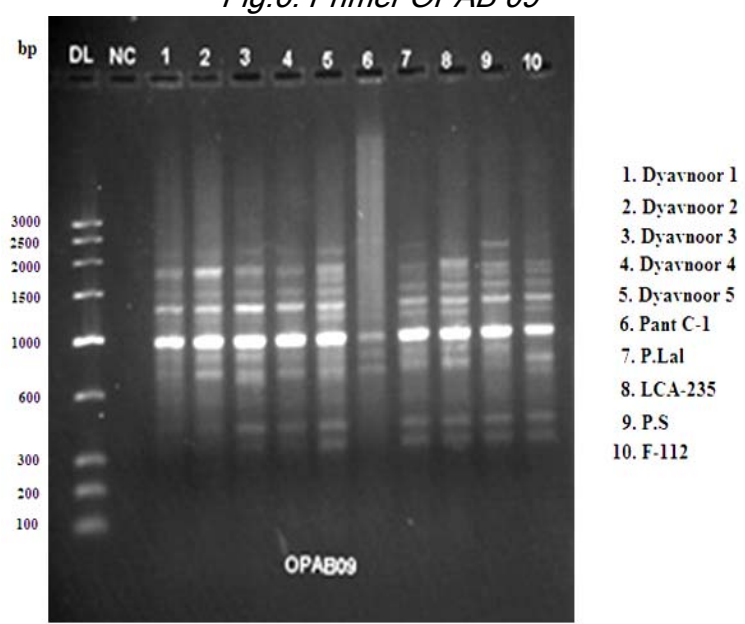

polymorphic band was observed in P.Lal in the range 600bp to 300bp so it can be as differential marker. With the primer OPW 19 (Fig. 12) amplification was observed in Dyavnoor3, Dyavnoor4, P.Lal, LCA-235, P.S \& F-112. Monomorphic band observed in LCA-235, P.S \& F-112 in the range $2000 \mathrm{bp}$ to $1500 \mathrm{bp}$. In the same way another chilli" Makari et al. Indian J.Sci.Technol. 
monomorphic band was observed in all the amplified

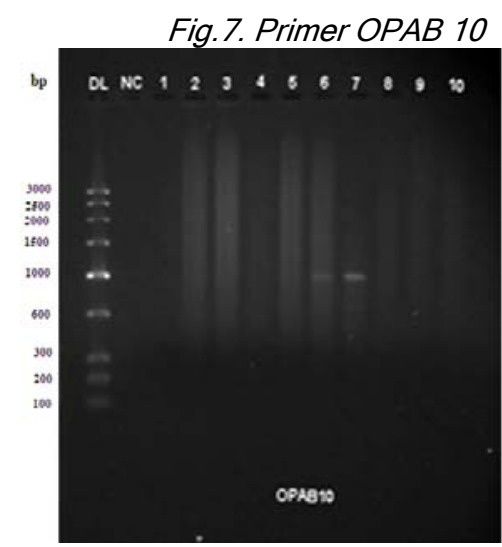

Fig.9. Primer OPA 18

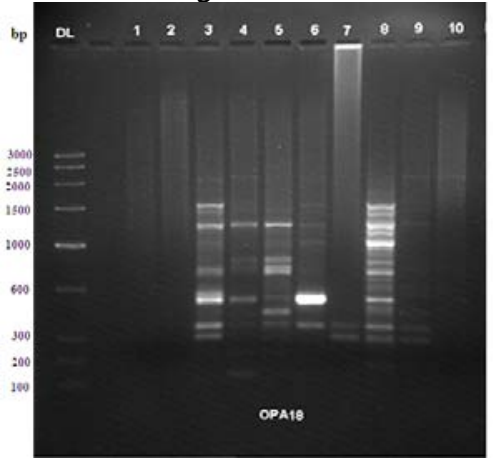

Fig. 11. Primer OPP 13

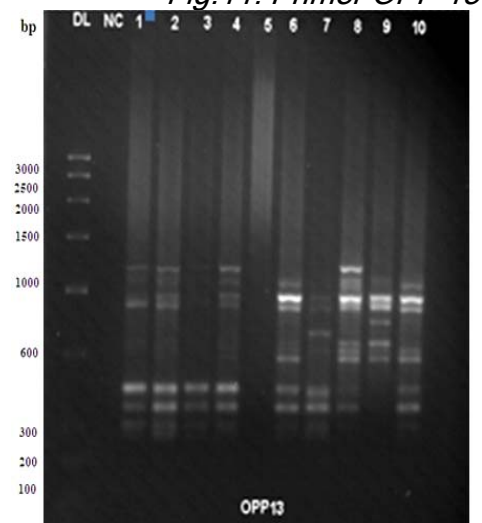

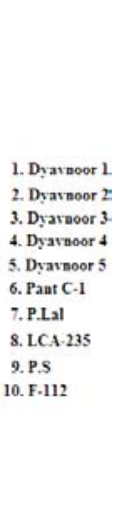

Fig.8. Primer OPAB 14

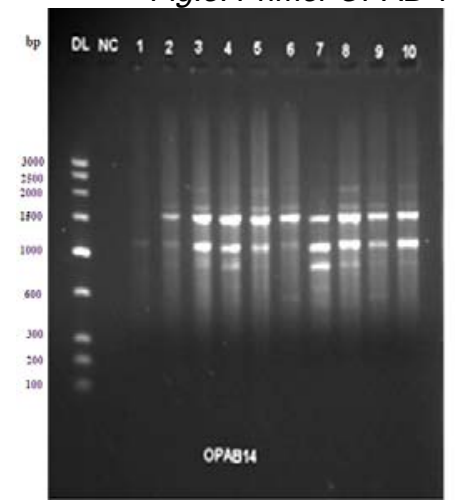

Fig. 10. Primer OPAB 20

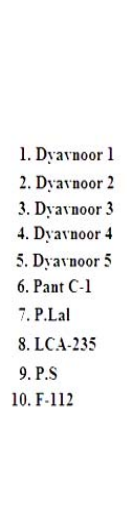

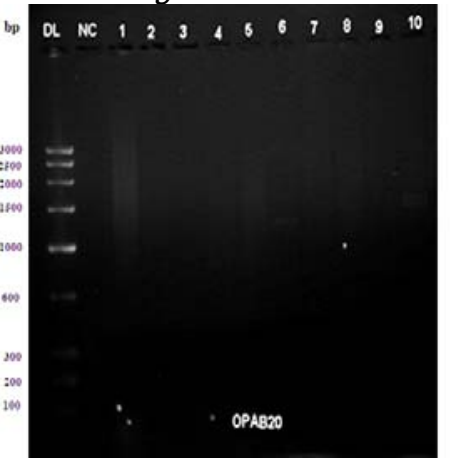

Fig. 12. Primer OPW 19

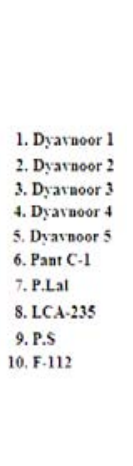$$
\text { by }
$$

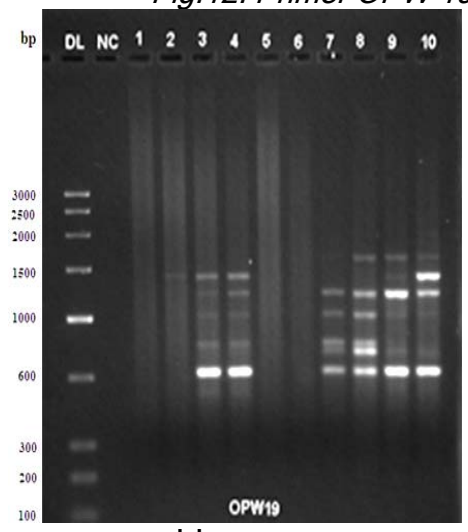

1. Dyarnoor 1

2. Dyarnoor 2

3. Dyarnoor 3

4. Dyarnoor 4

5. Dyarnoor 5

6. Pant C-1

7. P.Lal

8. LC.A-235

9. P.S

10. F-112 varieties in the range of $600 \mathrm{bp}$ to $300 \mathrm{bp}$. A monomorphic band was also observed in the P.Lal \& LCA-235 in the range of $1000 \mathrm{bp}$ to $600 \mathrm{bp}$.

\section{Conclusion}

The results of this study establish that when an appropriately chosen set of primers is employed, RAPD analysis provides an alternative rapid, reproducible, and powerful genomic typing method for finding the genetic diversity in some chilli plant varieties of same species.

\section{References}

1. Agwana CO, Lashermes $P$, Trouslot $P$, Combes $M$ and Charrier A (1997) Identification of RAPD markers for resistance to coffee berry disease, Colletotrichum kahawae, in arabica coffee. Euphytica. 97, 241-248.

2. Alahakoon PW, Brown AE and Sreenivasaprasad S (1994) Cross-infection potential of genetic groups of Colletotrichum
1024-1031.

10. Hong JK and Hwang BK (1998) Influence of inoculum density, wetness duration, plant age, inoculation method, Colletotrichum coccodes. Plant Disease. 82, 1079-1083.

11. Jordi B and Carmen M (1998) Determination of F1 hybrid seed purity in pepper using PCR- based markers. Euphytica. 103, 223-226.

12. Joseph A (1993) A taxocological review capsaicinoid (oleorecin of capsicums). Ruddick Hazardous Product Section, Environmental Health, Directorate Health and Welfare, Canada.

13. Martínez-Culebras PV, Barrio E, García MD and Querol A (2000) Identification of Colletotrichum

14. species responsible for anthracnose of strawberry based on the internal transcribed spacers of the ribosomal region. FEMS Microbiol. Letters. 189 (1), 97-101.
Research article

CIndian Society for Education and Environment (iSee)
"Molecular marker for chilli" http://www.indjst.org
Makari et al. Indian J.Sci.Technol. 